\title{
Trade Flows between Czech Republic and East Asia
}

\section{Shoiw-Mei Tseng ${ }^{1}$}

\begin{abstract}
Since 2005, Czech Republic has succeeded in transforming its economy through international trade surplus. However, Czech Republic's trade deficits with East Asia are burgeoning, not only in China but also in other East Asian countries. This study provides an insight into Czech Republic's import/export performance in East Asia during 1999-2011. In this study, the geographic concentration of trade, on a macro view, is adapted to highlight Czech Republic's new regional market of East Asia in contrast with its trade expansion in the world. In consideration of the general development of world trade, the probability model of trade flows, on a micro view, is employed to investigate Czech Republic's trade flows of East Asian countries. The result suggests that Czech Republic is bound to encounter continuing trade imbalance with East Asia. Nevertheless, Czech Republic's trade geographic concentration in East Asia has the potential to relax.
\end{abstract}

Key words: geographic concentration, Gini-Hirschman coefficient, probability model, trade flows.

JEL Classification: F14

\section{Introduction}

Trade liberalization in Central and Eastern Europe (CEE) responded very quickly to the new regime and shifted away from the Council for Mutual Economic Assistance (CMEA) and toward the European Union (EU) markets at the beginning of the economic transformation (Gros and Gonciarz 1996; Richter 1994, pp.183). According to the Czech Statistical Office (CZSO), Czech Republic's trade with the EU15 ${ }^{2}$ expanded considerably - the Czech total trade volume of $25 \%$ in 1980 s rose to about $70 \%$ in 1995 , while decreasing from $40 \%$ to less than $10 \%$, respectively, with CMEA. Hamilton and Winters (1992) mentioned that this liberalization has an impact on the global trading system, including new supplies of goods and export market opportunities on a scale.

Certainly, the EU $27^{3}$ seizes largely these opportunities, accounted for over $85 \%$ of Czech Republic's exports and 70\% of imports during 1995-2011. Meanwhile, given the huge foreign direct investment (FDI) from the EU15, the spillovers of technology transfer had a vital effect on Czech Republic's international trade structure (Kosová 2005; Lipsey 2006; Hamplová et al. 2012, pp.239). According to The Global Competitiveness Report 2012-2013 by the World Economic Forum, Czech Republic is

\footnotetext{
${ }^{1}$ Assistant Professor, Department of International Business, I-Shou University. Add: No.1, Sec. 1, Syuecheng Rd., Dashu District, Kaohsiung City 84001,Taiwan; e-mail: wisnia@isu.edu.tw

${ }^{2}$ EU member countries prior to the accession of ten candidate countries on 1 May 2004

${ }^{3} \mathrm{EU}$ member countries after the enlargement in 2007
} 
ranked 18th in FDI and technology transfer (WEF 2012, pp.151). Consequently, Czech Republic's imports do not rely much on the EU15 (64\% of total imports in 1999 reduced to $48 \%$ in 2011), although the EU15's share of Czech Republic's exports reduced just slightly to $63 \%$ in 2011 from $69 \%$ in 1999. Besides, as an EU member state, Czech Republic fosters international competitiveness and significantly accelerates external trade (Janáček and Zamrazilová 2005). Czech Republic saw surplus from 2005; the surplus amounted to $€ 7.8$ billion in 2011 .

Myant (2007) demonstrated that the economic transformation in Czech Republic, creating a "functioning market economy", has succeeded to a future perspective. Numerous studies suggest that openness of international trade speeds up economic growth (Westernhagen 2002, pp.110). To ensure economic growth, Czech Republic needs to expand widely its foreign trade, not only in the EU but also in the rest of the world. Owing to a historical linkage, the trade with countries of former Soviet Union recently improved in terms of both imports and exports (6\% in 1999 to $8 \%$ in 2011 and $3 \%$ in 1999 to 5\% in 2011, respectively). More particularly, Czech Republic's imports from Asia were very dynamic-8\% in 1999 to $23 \%$ in 2011 - while the share of total imports from other continents were declining. Contrarily, Czech Republic's exports to Asia were at almost constant rates, around 3 to $4 \%$ of total exports during 1999-2011. Clearly, the trade deficit in Asia soared from $€ 1.3$ billion in 1999 to $€ 19.4$ billion in 2011. This deficit arises apparently from East Asia, which shared nearly $90 \%$ of Czech Republic's imports in Asia and 50\% of the exports. ${ }^{4}$ The trade deficit in East Asia was $€ 1.4$ billion in 1999 to $€ 19.1$ billion in 2011 . China's rise may be thought of as the cause of imbalance trade in East Asia, as the other EU countries confront. However, during the past decade, the trade deficits were constantly augmenting in most East Asian countries, except Hong Kong (see Table 1). Along with dramatical growth of trade, bilateral trade imbalance has become more prominent.

Table 1: Trade balance between Czech Republic and East Asian countries in 20022011 (in $€$ million)

\begin{tabular}{c|cccccccccc}
\hline & 2002 & 2003 & 2004 & 2005 & 2006 & 2007 & 2008 & 2009 & 2010 & 2011 \\
\hline China & -1835 & -2148 & -2634 & -2927 & -4212 & -6203 & -7994 & -6970 & -10823 & -12399 \\
Hong Kong & 53 & 22 & 15 & 9 & 45 & 161 & 105 & 165 & 168 & 220 \\
Indonesia & -104 & -90 & -97 & -92 & -141 & -129 & -138 & -151 & -198 & -212 \\
Japan & -744 & -886 & -1677 & -1691 & -1925 & -2436 & -2834 & -2058 & -1922 & -1815 \\
Malaysia & -439 & -560 & -429 & -337 & -477 & -586 & -548 & -493 & -639 & -838 \\
Philippines & -206 & -266 & -224 & -65 & -29 & -36 & -54 & -57 & -70 & -96 \\
Singapore & -150 & -134 & -66 & -47 & -67 & -191 & -463 & -451 & -717 & -527 \\
South Korea & -292 & -299 & -407 & -392 & -475 & -607 & -833 & -814 & -1402 & -1619 \\
Taiwan & -484 & -484 & -504 & -586 & -861 & -858 & -833 & -634 & -883 & -736 \\
Thailand & -80 & -162 & -154 & -279 & -354 & -521 & -759 & -782 & -1118 & -892 \\
Vietnam & -38 & -31 & -47 & -58 & -83 & -93 & -149 & -148 & -158 & -237 \\
\hline
\end{tabular}

\footnotetext{
${ }^{4}$ The East Asian countries are listed in the methodology section of this study.
} 
The fact is that there is a relative balance in development in the East Asia region, unlike in the EU, but as Gill et al. (2007, pp.2) stated, there is no region as divergent as East Asia. Not only does the population range from 1.3 billion in China to 5.4 million in Singapore, and nominal GDP per capita from US\$1,300 in Vietnam to near US\$50,000 in Singapore and Japan ${ }^{5}$, there are many differences in resource endowments, business regulations, and political systems. The basic indicators of the main East Asian countries are displayed in Table 2. Indeed, it is challenging to conduct a comparative study of Czech Republic's trade with each East Asian country simultaneously. Therefore, this study attempts to provide an insight into Czech Republic's import/export performance in the new market of East Asia.

In a word, Czech Republic's international trade structure has transformed from CMEA to EU, and then returns to the former Soviet Union and accelerates in East Asia. Thanks to globalization and ease of communication, transaction costs of international trade have greatly decreased. As we can see, Czech Republic's business practices are increasing within East Asian countries, but little research has been done on this topic. Hence, on the macro view, the objective of this study is to highlight Czech Republic's new regional market of East Asia in contrast with its trade expansion in the world. Furthermore, on the micro, the objective is to investigate Czech Republic's trade flows of East Asian countries and find out bilateral trade relationship.

This paper first discusses an appropriate methodology of international trade and introduces the sample countries. The following section analyzes the results on both the macro and micro views. A conclusion summarizes the main findings.

Table 2: Basic indicators of East Asian Countries in 2011

\begin{tabular}{c|crrrr}
\hline & $\begin{array}{c}\text { Population } \\
\text { (thousand) }\end{array}$ & $\begin{array}{c}\text { Area(sq. } \\
\text { km) }\end{array}$ & $\begin{array}{r}\text { GDP per capital } \\
\text { (US\$) }\end{array}$ & $\begin{array}{c}\text { Import (million } \\
\text { US\$) }\end{array}$ & $\begin{array}{c}\text { Export (million } \\
\text { US\$) }\end{array}$ \\
\hline China & $1,343,240$ & $9,596,961$ & 5,433 & $1,743,000$ & $1,904,000$ \\
Hong Kong & 7,154 & 1,104 & 34,011 & 482,600 & 427,900 \\
Indonesia & 248,645 & $1,904,569$ & 3,401 & 166,100 & 201,500 \\
Japan & 127,368 & 377,915 & 46,079 & 808,400 & 788,000 \\
South Korea & 48,861 & 99,720 & 22,841 & 524,400 & 556,500 \\
Malaysia & 29,180 & 329,847 & 9,551 & 177,100 & 225,600 \\
Philippines & 103,775 & 300,000 & 2,053 & 62,680 & 47,230 \\
Singapore & 5,353 & 697 & 48,529 & 366,300 & 414,800 \\
Taiwan & 23,235 & 35,980 & 20,090 & 279,400 & 307,100 \\
Thailand & 67,091 & 513,120 & 5,151 & 196,300 & 221,600 \\
Vietnam & 91,519 & 331,210 & 1,341 & 97,830 & 95,320 \\
\hline
\end{tabular}

Source: The World Factbook, CIA, retrieved on November 05, 2012, from

https://www.cia.gov/library/publications/the-world-factbook/, page last updated on October 4, 2012.

\footnotetext{
${ }^{5}$ The data are GDPs in current price divided by populations in 2011, based on The World Factbook, CIA, retrieved from https://www.cia.gov/library/publications/the-world-factbook/ on November 5, 2012,, page last updated on October 4, 2012.
} 


\section{Methodology}

Since David Ricardo introduced the law of comparative advantage in 1817, international trade theory has developed extensively to examine trade patterns or factor endowments in a complex trade flow, such as the Heckscher-Ohlin theory and the gravity model. Djankov and Freund (2002), however, argued that in central-planned systems, the trade flow is largely a result of political borders and historical linkages, and not a result of comparative advantage and tastes. Before 1990, international trade practices in the postcommunist countries did not operate under market economy. After 1990, they learned quickly through marketing and the trade mostly shifted toward western Europe due to geographic proximity. With regard to East Asia, Czech Republic's marketing did not respond quickly to trade, but gradually moved toward this region in a trial-and-error method of learning. In this diverse region of East Asia, this study is interested in tracking the path of trade flows rather than the complex factor endowment of such trialand-error marketing. Hence, this study applies a simple coefficient of geographic concentration and probability model of trade flows to investigate the trade between Czech Republic and East Asia during 1999-2011. Beginning with 1999 has two major considerations, the Czechoslovakia's Velvet Divorce in 1993 and East Asian Financial Crisis in 1997-1998.

The Gini-Hirschman coefficient, the most popular index of inequality, has been used to measure trade concentrations in debates of export instability since the 1960s (Love 1987; MacBean 1980; Tegegne 1991). This study, following Love (1979), applies the GiniHirschman coefficient to delineate geographic concentrations of trade (TGC) in a given region. A Gini-Hirschman index of zero represents perfect equality, while an index of 100 implies perfect inequality. The degree of geographic concentration of a country's import portfolio in a given region is defined as $G_{i j m t}$ :

$G_{i j m t}=100 \sqrt{\sum_{j=1}^{n}\left(\frac{m_{i j t}}{m_{i t}}\right)^{2}}$

where $m_{i j t}$ is the import value of country $i$ from country $j$ of a given region in year $t$, and $m_{i t}$ is $i$ country's total import value in a given region in that year.

In the same measure, $G_{i j x t}$ defines as the geographic concentration degree of a country's export in a given region:

$G_{i j x t}=100 \sqrt{\sum_{j=1}^{n}\left(\frac{x_{i j t}}{x_{i t}}\right)^{2}}$

where $x_{i j t}$ is the export value of country $i$ to country $j$ of a given region in year $t$, and $x_{i t}$ is $i$ country's total export value in a given region in that year. 
A high TGC coefficient indicates that a country's trade depends on few countries in a given region, and vice versa. This study focuses on East Asia, and two other region groups are added for contrasting: world (WL) and top ten trade partners (W10). To sum up, there are six TGCs calculated in this study, grouped as "Czech import from WL" (WLm), "Czech export to WL" (WLx), "Czech import from W10" (W10m), "Czech export to W10" (W10x), "Czech import from EA" (EAm), and "Czech export to EA" $(\mathrm{EAx})$. The countries grouped under WL and W10 are according to the external trade database of CZSO, which is our source of TGC data for 1999-2011.

Regardless of which countries represent the world (WL) and the top ten trade partners (W10) for each year, this study follows the CZSO database selection to present the WL and W10 countries. There is a slight discrepancy in WL countries each year, but the number of countries is about 200. The TGC of WL represents the general status of the geographic concentration of Czech Republic's imports/exports in the world, whereas that of W10 represents their detailed status among the major trade partners. Both represent Czech Republic's trade dependency in different region group definitions. In our target group, EA, eleven countries have been selected including China, Hong Kong, Indonesia, Japan, South Korea, Malaysia, Philippines, Singapore, Thailand, Taiwan, and Vietnam, which cover most of the Association of South-East Asian Nations (ASEAN) and Asia Pacific Zone countries. This study excludes those countries ever with insignificant trade values ${ }^{6}$ with Czech Republic and that do not appear in the list of Czech Republic's top 50 trade partners, which include Brunei Darussalam, Cambodia, Laos, Myanmar, Mongolia, and North Korea. Table 3 shows the sample coding of TGC in this study.

Table 3: The sample coding for geographic concentrations of trade

\begin{tabular}{c|l}
\hline code & Description \\
\hline EA & East Asia \\
WL & World \\
W10 & top ten trade partners of Czech Republic \\
EA $m$ & Czech import from East Asia \\
EA $x$ & Czech export to East Asia \\
WL $m$ & Czech import from the world \\
WL $x$ & Czech export to the world \\
W10m & Czech import to the top ten trade partners \\
W10x & Czech export to the top ten trade partners \\
\hline
\end{tabular}

Source: own table.

Noteworthily, Spiezia (2003) argued that the absolute Gini-Herfindahl index is not suitable for direct comparisons of disparities between regions owing to a bias of grouping and the number of countries. In this study, TGCs are used to highlight the path of a given region as a whole in time series, and not to compare any signal coefficient between regions in detail. To investigate a macro trend of TGC, a two-tailed Pearson's

${ }^{6}$ The import or export volumes are zero or near zero. 
correlation coefficient is calculated between a TGC variable and a time series (19992011), which is denoted in this study by Pearson's $R$ and gives a value between +1 and -1 inclusive. Additionally, the coefficient of variation (CV), also known as relative standard deviation, is used to measure TGC dispersion of a probability distribution, which is expressed as an index equal to 100 .

At a micro level, Leamer and Stern (2009, pp.158) mentioned that there are three models to describe the trade flows, including gravity model, general-equilibrium model, and probability model. They also proposed the preferred model of probability approach by Savage and Deutsch in 1960 (Savage and Deutsch 1960), characterized by demanders being assigned to suppliers in a random fashion. This study employs the simple model to measure the trade flow between a pair of countries. The export flow ratio (EFR) of this study is computed as follows:

First, $P_{i x t}$ is defined as the proportion of country $i$ 's export in the total world export in year $t$ :

$P_{i x t}=\frac{X_{i t}}{W_{x t}}$

where $X_{i t}$ is the total export value in year $t$, and $W_{x t}$ is the world total export value in that year.

Second, $P_{j m t}$ is the proportion of country $j$ 's import in the total world import in year $t$ :

$$
P_{j m t}=\frac{M_{j t}}{W_{m t}}
$$

where $M_{j t}$ is the total import value in year $t$, and $W_{m t}$ is the world total import value in that year.

Equation (1) multiplied by equation (2) is $P_{i j x t}$, the probability of country $i$ 's export to that country $j$ 's, as a theoretical EFR:

$$
P_{i j x t}=P_{i x t} P_{j m t}
$$

The world total export value ( $W_{x t}$ ) multiplied by equation (3) is $N_{i j x t}$, the theoretical value of country $i$ 's export to country $j$ 's:

$$
N_{i j x t}=W_{x t} P_{i j x t}
$$

The actual export value divided by equation (4) is $F_{i j x t}$, named EFR of country $i$ to country $j$ : 


$$
F_{i j x t}=\frac{A_{i j x t}}{N_{i j x t}}
$$

where $A_{i j x t}$ is the actual export value of country $i$ to country $j$, which matches the data sourced from CZSO.

In the same measure, $F_{i j m t}$ is defined as the import flow ratio (IFR):

$$
F_{i j m t}=\frac{A_{i j m t}}{N_{i j m t}}
$$

where $A_{i j m t}$ is the actual import value of country $i$ from country $\mathrm{j}, N_{i j m t}$ is the theoretical import value of country $i$ from country $j$ as the equation (4).

In other words, the trade flow ratio is projected as the level of actual trade from country $i$ to $j$ with $i$ 's overall inclination to export and with $j$ 's inclination to import in consideration of the general development of world trade. A ratio equal to 100 is defined as a normal trade relationship. Certainly, under such a dynamic trade expansion in the Czech Republic, bilateral trade terms differ for each country, or for each year. This study assumes that the discrepancy does not influence the trade values of each country.

The data for trade flows are sourced from World Trade Organization (WTO) for 19992011, except of $A_{i j x t}$ and $A_{i j m t}$. It is noteworthy that in general statistical methods, according to WTO, exports are valued at transaction value, including the cost of transportation and insurance to bring the merchandise to the exporting country's frontier (free on board, FOB), and imports are valued at transaction value plus the cost of transportation and insurance to the importing country's frontier (cost insurance and freight, CIF), so that the statistics of world's overall exports is not equal to that of imports (about 3\% differences during our study period). This data limitation is also seen in CZSO data. Furthermore, the US dollar is selected as the data currency, of both WTO and CZSO, in these methods.

Then, to examine EFR and IFR in time series, descriptive statistics such as means, minimum, maximum, and range, as well as Pearson's $R$ and $\mathrm{CV}$, are applied. Comparatively, among the sample countries, the Pearson's $R$ is a measure of the strength between trade flow ratios and years (1999-2011), and the CV is a measure of the volatility in the study period of 13 years. The coding of trade flow analysis is shown in Table 4. 
Table 4: The sample coding for trade flows

\begin{tabular}{|c|c|}
\hline code & description \\
\hline $\mathrm{CNm}$ & Czech import from China \\
\hline $\mathrm{CN} x$ & Czech export to China \\
\hline $\mathrm{HK} m$ & Czech import from Hong Kong \\
\hline $\mathrm{HK} x$ & Czech export to Hong Kong \\
\hline ID $m$ & Czech import from Indonesia \\
\hline IDx & Czech export to Indonesia \\
\hline $\mathrm{JP} m$ & Czech import from Japan \\
\hline $\mathrm{JP} x$ & Czech export to Japan \\
\hline $\mathrm{KR} m$ & Czech import from South Korea \\
\hline $\mathrm{KR} x$ & Czech export to South Korea \\
\hline MYm & Czech import from Malaysia \\
\hline MYx & Czech export to Malaysia \\
\hline $\mathrm{PH} m$ & Czech import from Philippines \\
\hline $\mathrm{PH} x$ & Czech export to Philippines \\
\hline $\mathrm{SG} m$ & Czech import from Singapore \\
\hline SG $x$ & Czech export to Singapore \\
\hline $\mathrm{TH} m$ & Czech import from Thailand \\
\hline $\mathrm{TH} x$ & Czech export to Thailand \\
\hline TWm & Czech import from Taiwan \\
\hline TW $x$ & Czech export to Taiwan \\
\hline $\mathrm{VN} m$ & Czech import from Vietnam \\
\hline $\mathrm{VN} x$ & Czech export to Vietnam \\
\hline
\end{tabular}

Source: own table.

\section{Results and Discussions}

The TGC indices of this study are shown in Table 5. Pearson's Rs for WL $x$, W10x, WLm, and W10m are negative and significant, suggesting that TGCs of the Czech Republic with the world partners and the top-ten world partners are slackening. It is evident that the Czech Republic gradually expands the global trade in a path to diversification, and cuts its dependence on EU.

On the contrary, the TGCs of the Czech Republic with East Asian partners, both in import $(\mathrm{EA} m)$ and export $(\mathrm{EA} x)$, are positive, revealing the trade concentration on few countries increasingly. The EAm index was 44.44 in 1999, and peaked to 63.92 in 2011, while that of the W10m and WLm was decreasing. Likewise, the EAx index was 38.65 in 1999, and increased to 48.41 in 2011, while that of the W10x and WL $x$ slowed down. Moreover, EA $m$ holds the highest CV, and is the only one augmented in 2004-2005, which was a turning period of Czech Republic accessing to EU. The 2008-2009 Global Financial Crisis and the latest euro crisis did not soften the EAm, but increased it to a peak.

In sum, the Czech Republic's regional market of East Asia is the lack of diversification in contrast with its trade expansion in the world. 
Table 5: The results of geographic concentrations of trade

\begin{tabular}{|c|c|c|c|c|c|c|}
\hline year & WL $x$ & W10x & $\mathrm{EA} x$ & WLm & $\mathrm{W} 10 \mathrm{~m}$ & $\mathrm{EA} m$ \\
\hline 1999 & 44.46 & 55.23 & 38.65 & 37.29 & 49.09 & 44.44 \\
\hline 2000 & 43.02 & 54.23 & 37.96 & 35.76 & 47.69 & 44.82 \\
\hline 2001 & 41.15 & 51.4 & 36.74 & 36.61 & 48.94 & 45.09 \\
\hline 2002 & 39.48 & 50.2 & 38.01 & 35.57 & 48.85 & 46.5 \\
\hline 2003 & 40.16 & 50.28 & 40.91 & 35.7 & 48.89 & 47.49 \\
\hline 2004 & 39.44 & 49.54 & 38.96 & 34.98 & 48.09 & 49.47 \\
\hline 2005 & 37.25 & 48.44 & 39.72 & 33.79 & 46.28 & 51.03 \\
\hline 2006 & 35.79 & 46.86 & 40.82 & 32.62 & 44.65 & 53.05 \\
\hline 2007 & 34.85 & 45.89 & 41.46 & 32.42 & 44.24 & 56.21 \\
\hline 2008 & 35.02 & 47.39 & 42.84 & 31.76 & 43.38 & 57.34 \\
\hline 2009 & 36.25 & 47.39 & 45.99 & 31.77 & 43.38 & 57.9 \\
\hline 2010 & 36.15 & 47.53 & 47.73 & 31.38 & 43.42 & 61.14 \\
\hline 2011 & 36 & 47.33 & 48.41 & 31.6 & 43.45 & 63.92 \\
\hline $\mathrm{CV}$ & 8.19 & 5.80 & 9.21 & 6.25 & 5.35 & 12.64 \\
\hline Pearson's $R$ & $-.901 * *$ & $-.874 * *$ & $.909 * *$ & $-.965^{* *}$ & $-.922 * *$ & $.984 * *$ \\
\hline
\end{tabular}

Note: ** Correlation is significant at the 0.01 level.

Source: own table.

On the micro views of trade flow analysis, the IFR is much higher than EFR for almost all the sample countries, as described in Table 6. The average IFR of East Asia in 19992011 is 43.6, five times more than the EFR (8.37). In an in-depth analysis of each country's performance, unsurprisingly, China plays an influential role, especially in Czech Republic's imports. The IFR of China $(\mathrm{CNm})$ was on average 86.44 during 1999-2011, while the EFR $(\mathrm{CN} x)$ was 8.14. Pearson's $R$ of $\mathrm{CN} m$ was positively significant and it peaked to 119.92 in 2011 , a rare case of exceeding a normal trade in all sample countries. As Fürst and Pleschová (2010) observed, China used the free markets in Central Europe to boost its own exports regardless of any substantial reciprocal compromises, even though the countries made efforts in China's favour. The IFR of Hong Kong (HKm) was clearly diluted by China: 7.25 in 1999 and 3.36 in 2011, and with a negative significance of Pearson's $R$. Nevertheless, Hong Kong, a laissezfaire economy characterized by free trade and low taxation, remained at a steady EFR $(\mathrm{HK} x)$ in our sample years, which is about 8 to 10. In other words, Hong Kong is the only country for which the average of EFRs exceeds the IFRs in this study. Taiwan was not affected by China as much as Hong Kong. Tubilewicz (2007) debates that Czech Republic has the most substantive relationship with Taiwan among CEE countries, both in political and economic diplomacy. The economic result is demonstrated by TWm with a high Pearson's $R$ and an average of 51.66. However, with regard to Czech 
Republic's exports, Pearson's $R$ of TW $x$ is small and insignificant. Vietnam, a former CMEA member with relationship with Czech Republic, had performed rather well in trade flows in the beginning. Because of political change and China's rise, however, the trade relationship has decreased sharply. For example, the VN $x$ fell from 30.13 in 1999 to 4.79 in 2011 . The VNm fell from 72.5 in 1999 to 46.93 in 2011 . It is a contrast to Fürst's (2010) discussion-an accelerating economic bond between Czech Republic and Vietnam (Fürst 2010, pp.283).

Japan, one of the largest national economies in the world, remains dynamic in both IFR $(\mathrm{JP} m)$ and EFR (JP $x)$ with very significant positive Pearson's $R \mathrm{~s}$, despite Japan's great recession in the past 20 years (Koo 2011). In fact, Japan is Czech Republic's major FDI investor and, recently, Czech Republic became the top recipient of Japanese FDI in CEE, especially in the automobile industry (Ikemoto 2005; Štrach and Everett 2006; Ikemoto 2007). South Korea rapidly caught up with the Japan in IFR (KRm), from 22.05 in 1999 to 58.3 in 2011 with a very significant positive Pearson's $R$, while Japan rose from 27.3 to 45.48 , respectively. The EFR (KRx) appears to have a great future development, from 3.04 in 1999 to 9.63 in 2011, unlike Japan which is down to 7.62 in 2011. The IFR of Thailand (THm) is quite similar to South Korea, increasing from 23.53 in 1999 to 71.31 in 2011 with a very significant positive Pearson's $R$, while the $\mathrm{TH} x$ is not significant. The IFR of Malaysia (MYm) is not significant in Pearson's $R$, but it holds high value averaging at 57.42 for 1999-2011 and at 67.06 in 2011. Singapore's international status resembles Hong Kong; however, the IFR (SGm) is not stable, averaging 21.13 for 1999-2011 and 31.69 for 2009-2011. The EFR (SGx) fell to 5.62 in 2011 from 19.67 in 1999, with a very significant negative Pearson's $R$. For Indonesia, both EFR (IDx) and IFR (IDm) are with non-significant Pearson's $R$, averaging at 6.87 and 25.28 for 1999-2011, respectively. The Philippines is a unique case, with exceedingly normal trade relationship in IFR (PHm) for 2003-2004. The random $\mathrm{PH} m$ numbers result in non-significant Pearson's $R$, as well as the $\mathrm{PH} x$. After 2004, the PH $x$ is at a constant, averaging at 14.16 for 2005-2011, which is the highest in our sample countries.

In sum, Czech Republic has no alternative in China's rise, expanding sharply on trade deficit. By contrast, Czech Republic and Vietnam cannot maintain the steady trade flows within the former CMEA relationship. Due to FDI, Japan sustains stable trade flows with Czech Republic. South Korea has augmented both the import and export flows, and Thailand has mushroomed in imports. The import flows of Malaysia and Taiwan have been consistently high. Hong Kong is an important partner for Czech Republic's exports, corresponding to its role as a transfer centre or an intermediary in international marketing. Singapore, as another export destination for the Czech Republic in East Asia, is unfortunately fading out. Indonesia has made no progress in both imports and exports. The export flow of the Philippines reveals a gradual potential growth. 
Table 6: Descriptive statistics of trade flow ratios in 1999-2011

\begin{tabular}{|c|c|c|c|c|c|c|}
\hline code & Mean & Minimum & Maximum & Range & $\mathrm{CV}$ & Pearson's $R$ \\
\hline $\mathrm{CNm}$ & 86.44 & 55.95 & 119.92 & 63.97 & 24.09 & $.870 * *$ \\
\hline $\mathrm{CN} x$ & 8.14 & 6.29 & 10.87 & 4.58 & 18.94 & $.569 *$ \\
\hline $\mathrm{HK} m$ & 5.35 & 2.31 & 9.44 & 7.13 & 40.96 & $-.608^{*}$ \\
\hline $\mathrm{HK} x$ & 9.11 & 7.19 & 10.72 & 3.53 & 9.72 & -0.108 \\
\hline $\mathrm{Id} m$ & 25.28 & 19.19 & 30.76 & 11.57 & 12.18 & -0.009 \\
\hline $\operatorname{Id} x$ & 6.87 & 5.01 & 9.75 & 4.74 & 20.52 & -0.083 \\
\hline $\mathrm{JP} m$ & 46.98 & 25.87 & 68.59 & 42.72 & 33.14 & $.749 * *$ \\
\hline $\mathrm{JP} x$ & 7.79 & 5.39 & 9.39 & 4.00 & 15.19 & $.713^{* *}$ \\
\hline $\mathrm{KR} m$ & 33.40 & 15.85 & 58.30 & 42.45 & 39.28 & $.921 * *$ \\
\hline $\mathrm{KR} x$ & 6.10 & 3.04 & 9.63 & 6.59 & 36.61 & $.653 *$ \\
\hline MYm & 57.42 & 28.60 & 92.70 & 64.10 & 29.47 & 0.208 \\
\hline MYx & 6.81 & 3.58 & 11.51 & 7.93 & 32.08 & -0.288 \\
\hline $\mathrm{PH} m$ & 48.46 & 7.56 & 129.84 & 122.28 & 76.44 & 0.039 \\
\hline PH $x$ & 11.80 & 3.39 & 22.40 & 19.01 & 43.92 & 0.340 \\
\hline $\mathrm{SG} m$ & 21.14 & 9.61 & 36.34 & 26.73 & 41.93 & 0.549 \\
\hline $\mathrm{SG} x$ & 10.49 & 4.00 & 23.08 & 19.08 & 57.44 & $-.918 * *$ \\
\hline $\mathrm{TH} m$ & 53.25 & 23.14 & 98.14 & 75.00 & 47.38 & $.935 * *$ \\
\hline ТH $x$ & 9.03 & 6.30 & 15.29 & 8.99 & 37.80 & -0.494 \\
\hline TWm & 51.66 & 33.66 & 66.19 & 32.53 & 18.41 & 0.525 \\
\hline TW $x$ & 4.33 & 3.08 & 6.20 & 3.12 & 20.62 & 0.089 \\
\hline $\mathrm{VN} m$ & 50.23 & 38.48 & 76.31 & 37.83 & 23.59 & $-.575^{*}$ \\
\hline $\mathrm{VN} x$ & 11.68 & 4.77 & 30.13 & 25.36 & 58.68 & $-.802 * *$ \\
\hline
\end{tabular}

\section{Conclusion}

The Czech Republic is ambitious in the world market after the collapse of the centrally planned system and the trade surplus began to unfold in 2005. In East Asia region, this study manifests the truth of Czech Republic's trade performance by means of geographic concentrations and trade flows.

According to the TGC analysis, the geographic concentrations in East Asia were still strong, in imports in particular. A stable trade relationship between China and Czech Republic emerged according to the trade flow analysis. Certainly, Czech Republic is expanding the other market space in East Asia. Japan and South Korea represented dynamic trade relationships with the Czech Republic, as well as Thailand's import. 
However, Vietnam, the most historical linkage with the Czech Republic, exhibited a sign of regress relationship. Likewise Hong Kong's import and Singapore's export were repositioned. Taiwan, one of the major FDI investor in the Czech Republic, regretfully displayed a weak relationship. With the highest $\mathrm{CV}$, Philippines featured the erratic relationship with Czech Republic.

Additionally, this study does not regard the prospects of Czech Republic's exports to East Asia in a short term, although Fürst (2010, pp.279) stated, East Asia has been viewed as a great opportunity for Czech exporters. Therefore, Czech Republic is bound to encounter the continuing trade imbalance with East Asia. Nevertheless, Czech Republic's trade geographic concentration in East Asia has the potential to relax, because there is a sign of the trade expansion to East Asian countries other than China.

\section{References}

DJANKOV, S., FREUND, C. (1996). Trade Flows in the Former Soviet Union, 1987 to 1996. Journal of Comparative Economics. 30(1), pp.76-90.

FÜRST, R. (2010). The Far East in the Czech Foreign Policy. In Kořan, M. (ed.), Czech Foreign Policy in 2007-2009: An Analysis. Prague: Institute of International Relations.

FÜRST, R., PLESCHOVÁ, G. (2010). Czech and Slovak Relations with China: Contenders for China's Favour. Europe-Asia Studies. 62(8), pp.1363-1381.

GILL, I.S., HUANG, Y., KHARAS, H.J. (2007). Perspectives on East Asian Development: An Introduction. In Gill, I.S., Huang, Y., Kharas, H.J. (eds.), East Asian Visions: Perspectives on Economic Development. Singapore: World Bank.

GROS, D., GONCIARZ, A. (1996). A Note on the Trade Potential of Central and Eastern Europe. Journal of Political Economy. 12(4), pp.709-721.

HAMILTON, C.B., WINTERS, A.L. (1992). Opening up International Trade with Eastern Europe. Economic Policy. (7)14, pp.77-116.

HAMPLOVÁ, E., PROVAZNÍKOVÁ, K., KOVÁRNÍK, J. (2012). Analysis of Impact of Direct Foreign Investment in the Czech Republic. In the 4th WSEAS World Multiconference on Applied Economics, Business and Development. Porto Portugal: ISEP, (ISBN: 978-1-61804-102-9, pp.235-240.)

IKEMOTO, S. (2005). Japanese Investments in the Central and Eastern Europe-In the Case of Czech Republic. Bulletin of Research Institute of Economic Science. 35, pp.2736.

IKEMOTO, S. (2007). Globalization and Japanese Investment in the Czech Republic. Bulletin of Research Institute of Economic Science. 37, pp.85-104.

JANÁČEK, K., ZAMRAZILOVÁ, E. (2005). Czech Economy: First Year After the EU Entry. Prague Economic Papers. 2005(3), pp.195-220.

KOO, R.C. (2011). The Holy Grail of Macroeconomics: Lessons from Japans Great Recession, Singapore: John Wiley \& Sons. 
KOSOVÁ, R. (2010). Do Foreign Firms Crowd Out Domestic Firms? Evidence from the Czech Republic. The Review of Economics and Statistics. 92(4), pp.861-881. DOI:10.1162/REST_a_00035

LEAMER, E.E., STERN, R.M. (2009). Quantitative International Economics. Third printing. New Jersey: Aldine Transaction.

LIPSEY, R.E. (2006). Measuring the Impacts of FDI in Central and Eastern Europe. NBER Working Paper. 12808.

LOVE, J. (1979). Trade Concentration and Export Instability. Journal of Development Studies. 15(3), pp.60-69.

LOVE, J. (1987). Export Instability in Less Developed Countries: Consequences and Causes. Journal of Economic Studies. 14(2), pp.3-80.

MacBEAN, A.I., Nguyen, D.T. (1980). Commodity Concentration and Export Earnings Instability: A Mathematical Analysis. The Economic Journal. 90(358), pp.354-362.

MYANT, M. (2007). Economic Transformation in the Czech Republic-A Qualified Success. Europe-Asia Studies. 59(3), pp.431-450.

RICHTER, S. (1994). Life Without CMEA: Foreign Trade in Eastern and Central Europe. In Gács, J., Winckler, G. (eds), International Trade and Restructuring in Eastern Europe. Heidelberg: Physica-Verlag.

SAVAGE, R. I., DEUTSCH, K.W. (1960). A Statistical Model of the Gross Analysis of Transactions Flows. Econometrioa. 28, pp.551-572.

SPIEZIA, V. (2003). Measuring Regional Economies. Statistics Brief OECD. No.6.

ŠTRACH, P., EVERETT, A.M. (2006). Japanese Foreign Direct Investment in the Czech Republic: A Motivational Analysis. Problems and Perspectives in Management. 1/2006, pp.22-31.

TEGEGNE, A. (1991). Commodity Concentration and Export Earnings Instability: Evidence from African Countries. The American Economist. 34(2), pp.55-59

TUBILEWICZ, C. (2007). Europe in Taiwan's Post-Cold War Foreign Relations. Diplomacy \& Statecraft. 18, pp.415-443. DOI: 10.1080/09592290701322606.

WEF (2012). The Global Competitiveness Report 2012-2013. Geneva: World Economic Forum.

WESTERNHAGEN, N. (2002). Systemic Transformation, Trade and Economic Growth: Developments, Theoretical Analysis and Empirical Results. Heidelberg: Physica-Verlag. 